\title{
Analisis Kualitas Air pada Jalur Distribusi Air Bersih di Gedung Baru Fakultas Ekonomi dan Manajemen Institut Pertanian Bogor
}

(Analysis of Water Quality of Water Distribution Channels in New Building of Faculty of Economics and Management Bogor Agricultural University (IPB))

\footnotetext{
Millah Hudiyah DB ${ }^{1}$ dan Satyanto Krido Saptomo ${ }^{{ }^{*}}$

${ }^{1}$ Departemen Teknik Sipil dan Lingkungan, Fakultas Teknologi Pertanian, Institut Pertanian Bogor. Jl. Raya Dramaga, Kampus IPB Dramaga, PO BOX 220, Bogor, Jawa Barat Indonesia

*Penulis korespondensi: saptomo@ipb.ac.id
}

Diterima: 22 Oktober 2018

Disetujui: 27 Maret 2019

\begin{abstract}
One of the causes of the decreasing of water quality was the increasing of inappropriate human activities that caused water pollution. Cihideung River was being made as water resource in the campus area which the water have been used for a lot of activities in IPB Dramaga Campus. The purpose of this research were to analyze the clean water quality from the ground water tank (GWT) in Cihideung to the new buildings of the FEM, to compare the result with a national quality standard, to determine the criteria of clean water quality based on STORET method, and to analyze the influence of time and weather to the water quality. The parameters which had concentration below the standard were TDS, turbidity, temperature, iron, fluoride, chloride, manganese, and sulfate, and biological parameters like the total coliform/E.coli. The parameters which exceeded the standard were the value of color of 60 TCU in Cihideung GWT at rainy afternoon and pH of 6.38 in wing 1 sanitary at rainy morning. According to the US-EPA system, the water quality of distribution channels of FEM new building were classified into grade $B$, that meant light contaminated.
\end{abstract}

Key words: distribution channels, quality standard, water pollution, water quality

\section{PENDAHULUAN}

Salah satu penyebab menurunnya kualitas air adalah meningkatnya kegiatan manusia yang tidak bijak sehingga menimbulkan pencemaran air pada sumber-sumber air. Kondisi tersebut dapat terjadi karena air menerima beban pencemaran yang melampaui daya dukungnya. Pencemaran air merupakan salah satu masalah yang sangat penting untuk diperhatikan, karena air sangat dibutuhkan dalam kehidupan. Keberadaan air yang tercemar akan sangat mengganggu sistem kehidupan, karena makhluk hidup membutuhkan air dengan kualitas yang baik dan kuantitas yang cukup serta ketersediaannya harus cukup kontinu (Sariwati 2010).
Salah satu sumber air yang digunakan oleh manusia adalah sungai. Air sungai yang keluar dari mata air biasanya mempunyai kualitas yang sangat baik. Namun dalam proses pengalirannya air tersebut akan menerima berbagai macam bahan pencemar (Sofia et al. 2010). Pencemaran air sungai sangat erat kaitannya terhadap kontinuitas aliran air sungai. Hal ini merupakan faktor klimatologis yang juga dipengaruhi musim, yaitu musim kemarau dan musim hujan. Variasi debit air dikarenakan musim dan berbagai kondisi lainnya yang menimbulkan perilaku serta variasi dari parameter kualitas air.

Sungai Cihideung merupakan salah satu sungai yang banyak dimanfaatkan untuk berbagai kegiatan manusia. Salah 
satu pemanfaatan air sungai di Sungai Cihideung adalah untuk pertanian, meskipun masih banyak di beberapa daerah yang menggunakannya untuk keperluan sehari-hari seperti mandi-cucikakus (MCK) (Waspodo et al. 2013). Sungai ini juga sebagai sumber air di kawasan kampus yang airnya dimanfaatkan untuk berbagai keperluan di Kampus Institut Pertanian Bogor (IPB) Dramaga. Besarnya aktivitas di sekitar sungai Cihideung membuat air sungai mudah tercemar oleh limbah domestik seperti dari tinja, limbah cair domestik, dan buangan kamar mandi.

Kampus IPB memiliki dua unit water treatment plant (WTP) yaitu WTP Cihideung dan WTP Ciapus dengan jumlah produksi dan pemrosesan yang berbeda. Pembangunan WTP Cihideung dilakukan pada tahun 1986 dengan kapasitas produksi air bersih yang dihasilkan sebesar 20 1/det dengan unit pemrosesan yang dimiliki sejumlah dua unit. WTP Ciapus dibangun pada tahun 1972 dengan daya produksi yang dihasilkan sebesar 7.5 1/det (Sariwati 2010). Tujuan penelitian ini adalah menganalisis kualitas air bersih berdasarkan parameter fisika, kimia, dan biologi dari bangunan GWT sampai gedung baru Fakultas Ekonomi dan Manajemen, menentukan kriteria mutu air bersih berdasarkan metode STORET, dan menganalisis pengaruh waktu pengukuran dan cuaca terhadap kualitas air.

\section{METODOLOGI}

Pengambilan data "Analisis Status Mutu Air dengan Metode Storet Pada Sistem Distribusi Air Bersih Di Gedung Baru Fakultas Ekonomi dan Manajemen IPB" dilakukan selama dua bulan, yaitu dari bulan Maret 2018 hingga April 2018. Pengambilan sampel air bersih pada sistem distribusi dilakukan di tiga tempat berbeda, yaitu WTP Cihideung, menara Fahutan, dan gedung baru Fakultas Ekonomi dan
Manajemen. Gedung baru FEM pengambilan sampel, yaitu toren wing 1 (gedung manajemen), toren wing 2 (gedung dekanat), toren wing 3 (gedung ESL), saniter wing 1 lantai 2, saniter wing 2 lantai 2, dan saniter wing 3 lantai 2.Pengambilan sampel ditunjukkan pada Gambar 1. Analisis status mutu air pada sistem distribusi terhadap sampel air bersih dilakukan di Laboratorium Limbah Padat dan Beracun, Departemen Teknik Sipil dan Lingkungan, Institut Pertanian Bogor.

Alat-alat yang digunakan dalam penelitian ini meliputi photometer, spektrofotometer, $\mathrm{pH}$ meter, TDS meter, turbidimeter, tabung reaksi, gelas kimia, gelas ukur, pipet, bulb pipet, labu erlenmeyer, labu ukur, oven, inkubator, lemari pendingin, timbangan, dan wadah botol plastik. Bahan yang digunakan dalam penelitian ini adalah reagent kimia, sampel air, akuades, alkohol $70 \%$, larutan baku sulfat, larutan buffer A dan B, larutan induk flouorida, larutan SPADNS dan asam zirkonil, serta membran uji petrifilm total coliform/E. Coli.

Sistem distribusi air bersih adalah pengaliran air melalui sistem perpipaan dari bangunan penampungan (reservoir) ke daerah pelayanan (konsumen). Penentuan mutu air pada sistem distribusi air bersih dilakukan melalui beberapa tahap, yaitu pengukuran, pengujian sampel, perhitungan, dan penilaian. Tahap pertama penelitian adalah pengambilan sampel pada jalur distribusi air bersih meliputi bangunan ground water tank (GWT) Sungai Cihideung sampai dengan Gedung baru Fakultas Ekonomi dan Manajemen serta pada gedung baru FEM pengambilan sampel, yaitu toren wing 1 (gedung manajemen), toren wing 2 (gedung dekanat), toren wing 3 (gedung ESL), saniter wing 1 lantai 2, saniter wing 2 lantai 2, dan saniter wing 3 lantai 2. Lokasi terdapat pada tiga titik yang akan ditunjukkan pada Gambar 1. Penentuan lokasi mengacu pada SNI 7828 Tahun 
2012 tentang Kualitas Air-Pengambilan Contoh-Bagian 5; Pengambilan contoh air minum dari instalasi pengolahan air dan sistem jaringan distribusi perpipaan. Standar yang digunakan dalam analisis data, yaitu pada Peraturan Menteri Kesehatan Republik Indonesia Nomor 32 Tahun 2017 tentang Standar Baku Mutu Kesehatan Lingkungan dan Persyaratan Kesehatab Air Untuk Keperluan Higiene Sanitasi, Kolam Renang, Solus Per Aqua, dan Pemandian Umum, dan Keputusan Menteri Lingkungan Hidup Nomor 155 Tahun 2003 tentang Pedoman Penentuan
Status Mutu Air dengan Metode storage and retrieval (STORET). Diagram alir penelitian ditunjukkan pada Gambar 1.

Parameter penentuan kualitas air bersih antara lain nilai TDS, kekeruhan, suhu, warna, kadar besi $\left(\mathrm{Fe}^{2+}\right)$, kadar fluorida (F), kadar klorida, kadar mangan $(\mathrm{Mn})$, kadar nitrit $\left(\mathrm{NO}^{2-}\right)$, keasaman $(\mathrm{pH})$, sulfat $\left(\mathrm{SO} 4{ }^{2-}\right.$ ), dan kadar total coliform/ E.coli. Metode pengujian parameter kualitas air bersih yang digunakan ditunjukkan pada Tabel 1.

Tabel 1 Metode pengujian parameter kualitas air bersih

\begin{tabular}{llll}
\hline \multicolumn{2}{c}{ Parameter } & Metode/alat yang digunakan & Metode analisis \\
\hline \multirow{4}{*}{ Fisika } & TDS & TDS HI 9835 & TDS meter \\
& Kekeruhan & Turbidimeter wagtech & Turbidimeter \\
& & & \\
& Suhu & pH meter HI 8424 & pH meter \\
& Warna & Photometer 8000 & Photometer \\
\hline \multirow{6}{*}{ Kimia } & Besi & Photometer 8000 & Photometer \\
& Fluorida & SNI 06-6989.29-2005 & Spektrofotometer \\
& Klorida & SNI 6989.19-2009 & Argentometri \\
& Mangan & Photometer 8000 & Photometer \\
& Nitrit & Photometer 8000 & Photometer \\
& pH & pH meter HI 8424 & pH meter \\
& Sulfat & SNI 6989.20-2009 & Spektrofotometer \\
\hline \multirow{2}{*}{ Mikrobiologi } & Total & & \\
& & & Petrifilm 3M
\end{tabular}

Pengambilan dan pengukuran sampel dari setiap titik dilakukan sebanyak empat kali pengukuran saat pagi cerah, pagi hujan, sore cerah, dan sore hujan. Hal tersebut untuk melihat pengaruh perbedaan waktu dan kondisi cuaca terhadap tingkat kualitas air. Nilai yang telah diperoleh dari hasil pengukuran selanjutnya dibandingkan dengan baku mutu yang digunakan. Sampel yang diuji akan menggambarkan kondisi kualitas air bersih pada sepanjang jalur distribusi mulai dari bangunan GWT (WTP Sungai Cihideung) sampai dengan Gedung baru Fakultas Ekonomi dan Manajemen.
Langkah-langkah penentuan mutu air menggunakan metode STORET yaitu:

1. Lakukan pengumpulan data kualitas air dan tentukan nilai maksimum, minimum dan rata-rata dari setiap parameter.

2. Bandingkan data hasil pengukuran (maksimum, minimum, dan rata-rata) dari masing-masing parameter air dengan nilai baku mutu.

3. Jika hasil pengukuran memenuhi nilai baku mutu air maka diberi skor 0 .

4. Jika hasil pengukuran tidak memenuhi nilai baku mutu maka diberi skor sesuai pada Tabel 3 (KemenLH 2003) 
5. Jumlah negatif dari seluruh parameter diakumulasikan sehingga diperoleh berdasarkan pada Tabel 2 (KemenLH nilai total yang digunakan untuk menentukan status mutunya 2003).

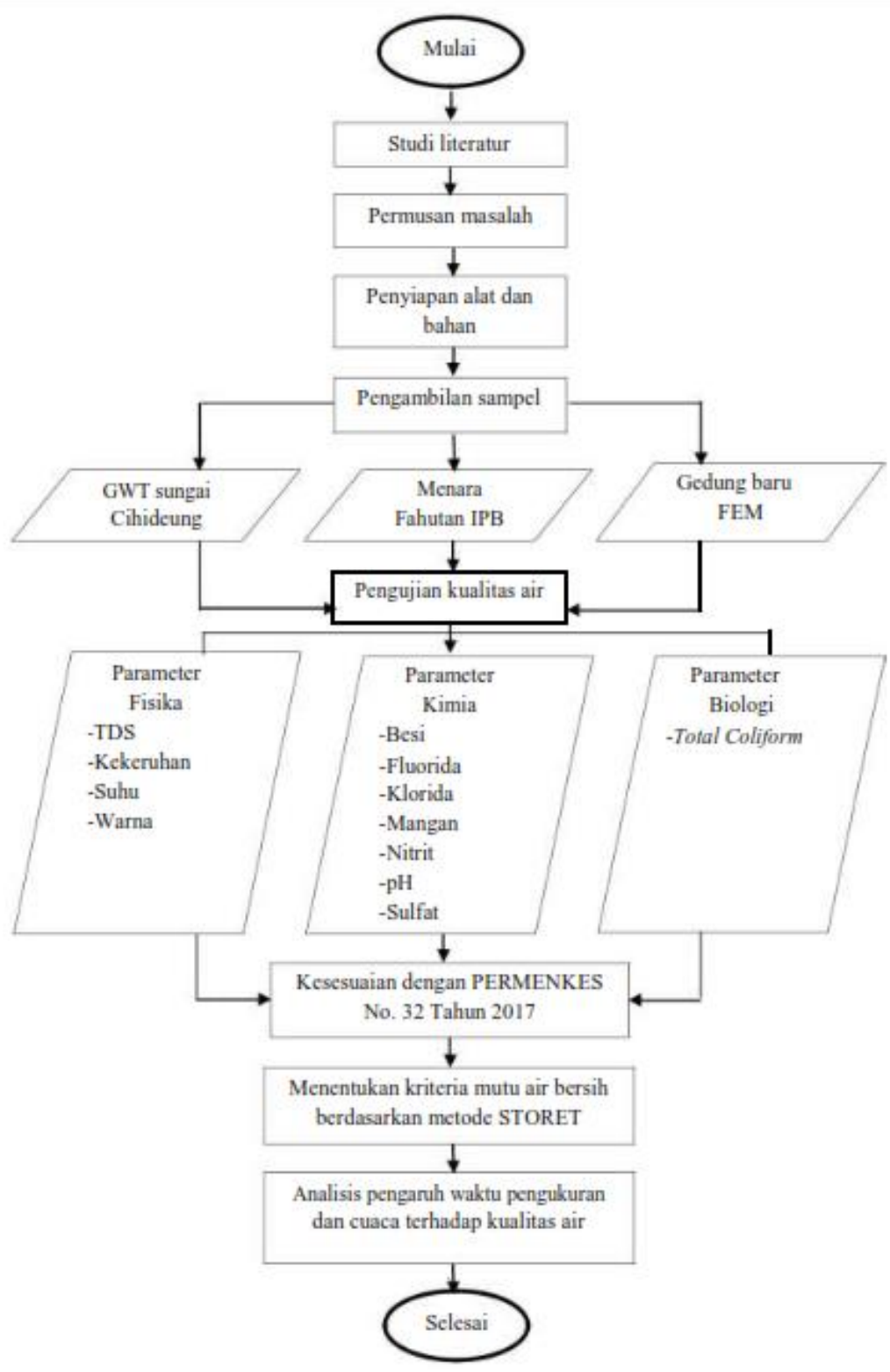

Gambar 1 Diagram alir penelitian

Tabel 2 Klasifikasi mutu air berdasarkan EPA

\begin{tabular}{llll}
\hline Kelas & Skor & Status & Keterangan \\
\hline A & 0 & Baik sekali & Memenuhi baku mutu \\
B & $-1 \mathrm{~s} / \mathrm{d}-10$ & Baik & Cemar ringan \\
C & $-11 \mathrm{~s} / \mathrm{d}-30$ & Sedang & Cemar sedang \\
D & $\geq-31$ & Buruk & Cemar berat \\
\hline
\end{tabular}


Prinsipnya, metode STORET membandingkan data kualitas air dengan standar baku mutu air dengan menggunakan sistem nilai dari US-EPA (United State-Environmental Protection Agency). Klasifikasi mutu air ada empat kelas seperti pada Tabel 2 (KemenLH 2003). Parameter-parameter yang telah memenuhi atau melampaui baku mutu air dapat diketahui dengan metode STORET. Penentuan status mutu air menggunakan sistem nilai yang mengklasifikasikan mutu air dalam 4 kelas sesuai Tabel 2. Sistem penilaian mengacu pada Tabel 3 sesuai dengan metode STORET. Nilai maksimun, minimum, dan rata-rata dari setiap parameter di total, kemudian diberi nilai. Penilaian menggunakan aturan untuk jumlah parameter lebih dari atau sama dengan 10.

Tabel 3 Penentuan sistem nilai

\begin{tabular}{clll}
\hline Jumlah & \multicolumn{2}{l}{ Parameter } & \\
\cline { 2 - 4 } Nilai & Fisika & Kimia & Biologi \\
\hline Parameter & -1 & -2 & -3 \\
<10Maks & -1 & -2 & -3 \\
Min & -3 & -6 & -9 \\
Rata-rata & -2 & -4 & -6 \\
$\geq 1$ Maks & -2 & -4 & -6 \\
Min & -6 & -12 & -18 \\
Rata-rata & & &
\end{tabular}

\section{HASIL DAN PEMBAHASAN}

\section{Analisis Jalur Distribusi Air Bersih}

Sistem distribusi air bersih di IPB memiliki berbagai jalur dengan sumber pendistribusian air berasal dari dua water treatment plant (WTP) yaitu WTP Cihideung dan WTP Ciapus. WTP Cihideung membagi distribusi air bersih dalam dua wilayah yang berbeda. Wilayah pertama mencakup Graha Widya Wisuda (GWW), Fakultas Pertanian (FAPERTA), gedung Gymnasium, gedung Common Class Room (CCR), Fakultas Kehutanan (FAHUTAN), Fakultas Matematika dan Ilmu Pengetahuan Alam (FMIPA), Fakultas Ekologi Manusia (FEMA), Fakultas Ekonomi dan Manajemen (FEM), Fakultas Teknologi Pertanian (FATETA), gedung SEAFAST, Perpustakaan IPB, gedung Rektorat Andi Hakim Nasoetion (AHN), dan Fakultas Ekonomi dan
Manajemen pada gedung baru. Wilayah kedua mencakup Fakultas Kedokteran Hewan (FKH), Fakultas Peternakan (FAPET), Fakultas Perikanan (FPIK), perumahan dosen IPB, masjid AlHurriyah, dan beberapa wisma serta asrama dari mahasiswa IPB. Jalur distribusi air dari WTP Ciapus mencakup wilayah asrama putra mahasiswa IPB dan asrama putri mahasiswa IPB.

WTP Cihideung memiliki empat GWT dengan masing-masing kapasitas yaitu $450 \mathrm{~m}^{3}, 600 \mathrm{~m}^{3}, 300 \mathrm{~m}^{3}$, dan $150 \mathrm{~m}^{3}$. Kebutuhan di wilayah pertama dengan dibangunnya menara Fahutan dengan ketinggian 25 meter berkapasitas $240 \mathrm{~m}^{3}$ dan masing-masing GWT berkapasitas 600 $\mathrm{m}^{3}, 300 \mathrm{~m}^{3}$, dan $1200 \mathrm{~m}^{3}$. Sedangkan untuk kebutuhan di wilayah kedua dengan dibangunnya menara Fapet dengan ketinggian 35 meter berkapasitas $100 \mathrm{~m}^{3}$ dan masing-masing GWT berkapasitas 300 $\mathrm{m}^{3}, 600 \mathrm{~m}^{3}$, dan $150 \mathrm{~m}^{3}$. Selain itu, kapasitas GWT gedung baru FEM sebelum 
dipompa pada masing-masing toren yaitu $48 \mathrm{~m}^{3}$ sedangkan kapasitas tiap toren yaitu $1.05 \mathrm{~m}^{3}$.

Berdasarkan proses wawancara dengan petugas WTP yang telah dilakukan, kapasitas produksi WTP Cihideung sebesar $216 \mathrm{~m}^{3} / \mathrm{jam}$ dan proses produksi dari WTP Cihideung terdiri dari tipe tekanan dengan kapasitas produksi sebesar $180 \mathrm{~m}^{3} / \mathrm{jam}$. Sedangkan tipe selanjutnya adalah tipe ultra filtration dengan kapasitas produksi sebesar $36 \mathrm{~m}^{3} / \mathrm{jam}$. Rata-rata air bersih yang dipompa dari GWT Cihideung ke menara Fahutan yaitu sebesar 180 $\mathrm{m}^{3} /$ hari. GWT di menara Fahutan pada sistem distribusi air bersih hanya dijadikan sebagai penampung air cadangan apabila terjadi peningkatan air yang signifikan.

Jalur distribusi wilayah pertama dari WTP Cihideung memiliki panjang 1.075 $\mathrm{km}$. Pipa yang digunakan berjenis pipa besi galvanis dengan diameter pipa sebesar 6 inci. Instalasi ini kemudian dilakukan proses penggantian jenis pipa menjadi pipa berjenis HDPE (high density poly ethylene) yang sudah terpasang dari WTP Cihideung hingga menara air belakang gedung CCR. Pemaparan nilai data dan keterangan didapat dari laporan hasil wawancara dengan petugas WTP dan pengawas bagian instalasi air Biro Umum IPB (Yudhantoro 2017).

\section{Analisis Kualitas Air Bersih}

Menurut Arsyad (2000), kualitas air menyatakan tingkat kesesuaian air untuk dipergunakan bagi pemenuhan kebutuhan tertentu bagi kehidupan manusia, seperti untuk mengairi tanaman, minuman ternak, serta kebutuhan langsung untuk diminum, mandi, mencuci, dan sebagainya. Kualitas air ditentukan oleh kandungan sedimen tersuspensi dan bahan kimia yang terlarut di dalam air tersebut. Setiap parameter kualitas air yang terukur memiliki kadar yang berbeda-beda, tergantung pada daerah dan aktivitas manusia yang terdapat di lingkungan tersebut. Menurut Atmojo et al. (2004), menyatakan bahwa aktivitas domestik dapat menjadi penyebab utama tingginya tingkat pencemaran di suatu perairan, khususnya total coliform. Jumlah coliform mengindikasikan tingkat pencemaran air di suatu lingkungan. Pengelolaan yang tepat sangat dibutuhkan untuk menjaga kelestarian lingkungan perairan.

Pengujian kualitas air bersih dibagi atas 3 parameter, yaitu fisika, kimia, dan biologi. Pengujian parameter fisika pada penelitian ini mencakup TDS, kekeruhan, suhu, dan warna. Parameter kimia yang diuji, meliputi besi, fluorida, klorida, mangan, nitrit $\mathrm{pH}$, dan sulfat, serta parameter biologi yaitu total coliform/E.Coli. Pengujian kualitas air bersih mengacu pada Peraturan Menteri Kesehatan Republik Indonesia Nomor 32 Tahun 2017 tentang Standar Baku Mutu Kesehatan Lingkungan dan Persyaratan Kesehatan Air Untuk Keperluan Higiene Sanitasi, Kolam Renang, Solus Per Aqua, dan Pemandian Umum. Berdasarkan hasil penelitian yang telah dilakukan, parameter yang melebihi baku mutu adalah nilai warna dan nilai $\mathrm{pH}$. Nilai parameter warna dari setiap lokasi titik sampling ditunjukkan pada Gambar 2.

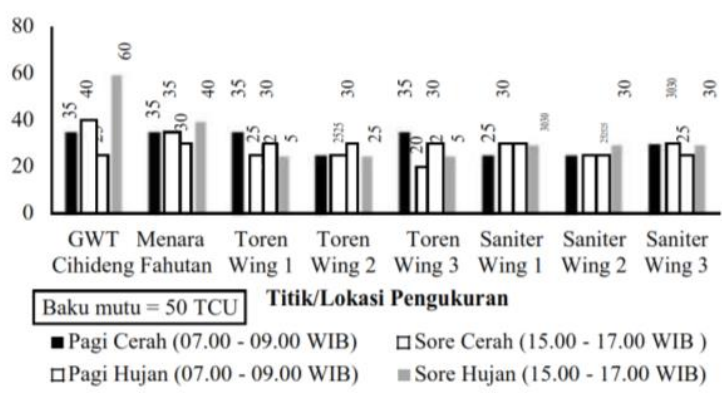

Gambar 2 Nilai warna sepanjang jalur distribusi air bersih

Nilai baku mutu kualitas air bersih untuk parameter warna sebesar 50 TCU. Berdasarkan hasil penelitian, nilai warna pada Gambar 2 cenderung fluktuatif. Nilai warna tertinggi pada kondisi sore hujan 
sebesar 60 TCU yang terdapat pada GWT Cihideung. Kondisi tersebut kemungkinan disebabkan oleh beberapa faktor yaitu, pengaruh cuaca hujan, adanya pembersihan WTP, dan kondisi reservoir yang kotor. Reservoir kotor disebabkan karena pada saat sore hari tingkat pemakaian air meningkat sehingga volume air pada reservoir tersebut hanya terisi $3 / 4$ dari volume total. Kondisi tersebut menyebabkan adanya endapan-endapan yang terbawa saat pengambilan sampel. Cuaca hujan mengakibatkan warna cenderung tinggi, karena pada saat hujan terjadi proses pengikisan tanah pada badan sungai dan terjadi proses penghamburan sedimentasi dalam sungai sehingga peningkatan warna pun terjadi.

Proses pemantauan kondisi perpipaan dan bak penampung air/reservoir perlu dilakukan untuk mengurangi kadar warna yang tinggi. Nilai warna terendah pada kondisi sore cerah sebesar 20 TCU terdapat pada toren wing 3 . Tingkat akurasi pada pengukuran warna dengan alat photometer yaitu $\pm 0.8 \% \mathrm{~T}$. Hasil yang didapat sesuai dengan hasil penelitian sebelumnya oleh Lazuardi (2016) dan Yudhantoro (2017) yang menunjukkan nilai warna pada saat hujan cenderung lebih tinggi dibandingkan dengan saat kondisi cerah.

Nilai $\mathrm{pH}$ dipengaruhi oleh beberapa faktor, antara lain aktivitas biologis (fotosintesis dan respirasi organisme), suhu, dan keberadaan ion-ion dalam perairan (Pescod 1973). Fardiaz (1992), nilai $\mathrm{pH}$ air yang terpolusi, misalnya air buangan berbeda-beda bergantung dari jenis buangannya. Sebagai contoh air buangan pabrik pengalengan mempunyai pH 6.2-7.6, air buangan pabrik susu dan produk-produk susu biasanya mempunyai $\mathrm{pH}$ 5.3-7.8, air buangan pabrik bir mempunyai $\mathrm{pH}$ 5.3- 7.8 sedangkan air buangan pabrik pulp dan kertas biasanya mempunyai $\mathrm{pH}$ 7.6-9.5. Peningkatan keasaman air buangan produksi pada industri makanan umumnya disebabkan oleh kandungan asam-asam organik. Nilai $\mathrm{pH}$ sangat mempengaruhi proses biokimiawi perairan, misalnya proses nitrifikasi akan berakhir jika $\mathrm{pH}$ rendah. Nilai $\mathrm{pH}$ yang kurang dari 4 dan lebih dari 11 akan menyebabkan kematian ikan (Boyd 1982).

Power of hydrogen $(\mathrm{pH})$ merupakan unit pengukuran yang menggambarkan derajat asiditas, alkalinitas suatu larutan, terutama sebagai indikator kualitas air. Nilai pH suatu perairan mencirikan keseimbangan antara asam dan basa dalam air. Nilai $\mathrm{pH}$ didefinisikan sebagai logaritma negatif dari ion hidrogen bebas (Wetzel 2001). Nilai pH menggambarkan konsentrasi ion hidrogen yang terkandung dalam perairan (Tebbut 1992). Nilai $\mathrm{pH}$ sangat mempengaruhi reaksi biokimia dalam air. Nilai parameter $\mathrm{pH}$ dari setiap lokasi titik sampling ditunjukkan pada Gambar 3.

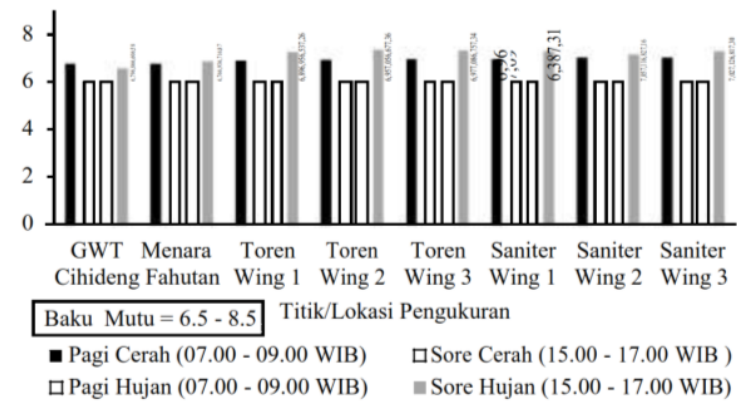

\section{Gambar 3 Nilai pH sepanjang jalur distribusi air bersih}

Nilai baku mutu kualitas air bersih untuk kadar $\mathrm{pH}$ yang diperbolehkan adalah 6.5-8.5. Berdasarkan hasil penelitian, nilai $\mathrm{pH}$ air sampel terendah didapat pada saat kondisi pagi hujan sebesar 6.38 yang terdapat pada saniter wing 1 (gedung manajemen) sedangkan nilai $\mathrm{pH}$ tertinggi pada saat kondisi sore hujan sebesar 7.36 
yang terdapat pada toren wing 2 (gedung dekanat). Nilai $\mathrm{pH}$ terendah memiliki nilai yang tidak sesuai dengan standar baku mutu yaitu kurang dari 6.5. Tingkat akurasi pada alat ukur $\mathrm{pH}$ meter yaitu 0.01 . Nilai $\mathrm{pH}$ yang tidak sesuai dipengaruhi oleh beberapa faktor yaitu pengaruh hujan yang bersifat asam dan adanya aktifitas dari pencemaran limbah organik. Tingginya limbah organik dalam air dapat meningkatkan aktivitas mikroorganisme di dalam air. Salah satu aktivitas mikroorganisme yang dimaksud antara lain proses fermentasi organik dari daun, tumbuhan air, hingga bangkai hewan yang menyebabkan penurunan nilai $\mathrm{pH}$ dalam air (Kurniawan 2014).

Derajat keasaman $(\mathrm{pH})$ air yang lebih kecil dari 6.5 atau $\mathrm{pH}$ asam meningkatkan korosifitas pada benda-benda logam, menimbulkan rasa tidak enak dan dapat menyebabkan beberapa bahan kimia menjadi racun yang mengganggu kesehatan (Sutrisno 2006). Air dengan pH yang tinggi mengakibatkan daya bunuh klorin terhadap mikroba berkurang selain itu $\mathrm{pH}$ juga merupakan parameter penting untuk air industri sebab air dengan $\mathrm{pH}$ yang rendah cenderung mengakibatkan korosi, sehingga diperlukan penanganan pendahuluan untuk menaikan $\mathrm{pH}$ (Cerny et al. 1971).

\section{Kriteria Mutu Air Bersih Berdasarkan Metode STORET}

Metode IP dan STORET mempunyai kesamaan yaitu memberikan fleksibilitas penentuan jumlah dan jenis parameter signifikan yang digunakan untuk menghitung indeks, namun flesibilitas ini dapat berdampak pada penyimpulan status mutu air (Saraswati et al. 2014). Metode STORET memiliki sensivitas lebih tinggi dibandingkan dengan metode indeks pencemaran. Hal tersebut dibuktikan dengan penggunaan bilangan ordinal untuk penilainya dengan membedakan niai setiap parameter berdasarkan tingkat pengaruhnya terhadap kualitas air. Penilaian metode indeks pencemaran berdasarkan rasio antara pengukuran dengan baku mutu.

Tabel 4 Penentuan nilai mutu air di tiap lokasi berdasarkan metode STORET

\begin{tabular}{lccl}
\hline Lokasi Pengambilan & Skor & Status & Keterangan \\
Sampel & & & \\
\hline GWT Cihideng & 0 & B & Cemar ringan \\
Menara Fahutan & A & Memenuhi baku mutu \\
Toren Wing 1 & 0 & A & Memenuhi baku mutu \\
Toren Wing 2 & 0 & A & Memenuhi baku mutu \\
Toren Wing 3 & 0 & A & Memenuhi baku mutu \\
Saniter Wing 1 & -4 & B & Cemar ringan \\
Saniter Wing 2 & 0 & A & Memenuhi baku mutu \\
Saniter Wing 3 & 0 & A & Memenuhi baku mutu \\
\hline
\end{tabular}

Titik pengambilan sampel pada GWT mempunyai skor -2 dan saniter wing 1 mempunyai skor -4. Lokasi pengambilan sampel untuk menara Fahutan, toren wing 1 , toren wing 2 , toren wing 3 , saniter wing
2, dan saniter wing 3 mempunyai skor 0 . Total akumulasi untuk jalur distribusi air bersih dari GWT cihideung hingga gedung baru FEM yaitu -6. Berdasarkan hasil analisis, klasifikasi status air pada sistem 
US-EPA (Tabel 2) maka air bersih pada jalur distribusi gedung baru FEM termasuk Kelas B yang artinya cemar ringan. Kondisi tersebut menunjukkan bahwa kualitas air pada gedung baru FEM tidak dapat digunakan untuk air minum, tetapi dapat digunkan untuk kegiatan seperti mandi, cuci tangan, wudhu, masak, dan penyiraman tanaman. Penentuan sistem nilai metode STORET pada tiap titik ditunjukkan pada Lampiran 3.

Rekomendasi yang dapat dilakukan untuk menangani parameter yang tidak memenuhi baku mutu antara lain dengan adanya proses pemantauan/pengawasan serta pemeliharaan dari kondisi perpipaan yang ada, proses kontrol pada wtp dan reservoir, hingga kondisi kran air yang digunakan pada setiap lokasi. Hal ini bertujuan agar kondisi air yang digunakan selalu dalam kondisi yang optimal dan dapat meminimalisir terjadinya pencemaran dengan nilai kadar dalam jangka panjang serta kualitas air dapat memenuhi baku mutu sesuai dengan permenkes no 32 Tahun 2017.

Berdasarkan pada Tabel 5, apabila kondisi pagi cerah dibandingkan dengan pagi hujan, dan sore cerah dibandingkan dengan sore hujan, maka dapat terlihat bahwa kualitas air saat cuaca cerah cenderung lebih baik dibandingkan dengan saat hujan. Hal tersebut disebabkan oleh terjadinya pengikisan pada badan sungai dan terjadinya dan terjadinya proses hamburan sedimentasi saat cuaca hujan. Fenomena tersebut berakibat pada peningkatan nilai warna, nilai kekeruhan, dan konsentrasi TDS.

Tabel 5 Rata-rata nilai parameter berdasarkan waktu dan cuaca

\begin{tabular}{llcccc}
\hline \multirow{2}{*}{ Parameter } & Pagi & Sore & Pagi & Sore \\
& & Cerah & Cerah & Hujan & Hujan \\
\hline \multirow{2}{*}{ Fisika } & TDS (mg/L) & 47.350 & 50.280 & 56.68 & 48.650 \\
& Kekeruhan (NTU) & 2.340 & 2.180 & 1.78 & 2.600 \\
& Suhu $\left({ }^{\circ} \mathrm{C}\right)$ & 26.850 & 25.580 & 27.19 & 24.460 \\
& Warna (TCU) & 30.630 & 28.750 & 28.13 & 33.130 \\
\hline \multirow{6}{*}{ Kimia } & Besi $(\mathrm{mg} / \mathrm{L})$ & 0.060 & 0.090 & 0.17 & 0.080 \\
& Fluorida(mg/L) & 0.070 & 0.080 & 0.07 & 0.060 \\
& Klorida(mg/L) & 10.720 & 12.310 & 10.14 & 10.310 \\
& Mangan(mg/L) & 0.002 & 0.001 & 0.01 & 0.001 \\
& Nitrit(mg/L) & 0.000 & 0.000 & 0.00 & 0.000 \\
& pH & 6.920 & 7.020 & 6.66 & 7.150 \\
& Sulfat(mg/L) & 6.120 & 5.270 & 6.87 & 4.360 \\
\hline Biologi & Total coliform & 0.090 & 0.120 & 0.04 & 0.060 \\
\hline & & & & &
\end{tabular}

Pemakaian air pada sore hari meningkat sehingga volume air dalam reservoir menjadi rendah dan terjadi pencampuran dengan sedimen yang terendap di reservoir dan kualitas airnya akan menurun. Aliran air baku menjadi turbulen pada kondisi hujan sehingga sedimen terbawa menjadi lebih banyak. Hal tersebut juga berpengaruh pada kualitas air yang diolah dan akan didistribusikan sehingga kepekatan warnanya berubah. Hal ini terlihat pada saat pagi hujan yaitu saat pengambilan sampel di pagi hari setelah malamnya hujan yang bertepatan dengan waktu pengisian reservoir yaitu malam hari. Kondisi tersebut mengakibatkan kualitas 
air yang didistribusikan akan lebih bagus saat pagi hari ketika cuaca cerah.

\section{SIMPULAN}

Simpulan yang dapat ditarik dari penelitian ini sebagai berikut.

1. Berdasarkan baku mutu yang berlaku, parameter yang tidak melebihi baku mutu pada jalur distribusi air bersih di gedung baru FEM adalah TDS, kekeruhan, suhu, besi, fluorida, klorida, mangan, dan sulfat, serta parameter biologi yaitu total coliform/E.Coli sedangkan yang melebihi baku mutu adalah nilai warna dan nilai $\mathrm{pH}$.

2. Nilai warna tertinggi pada kondisi sore hujan sebesar 60 NTU yang terdapat pada GWT Cihideung. Nilai $\mathrm{pH}$ air sampel terendah didapat pada saat kondisi pagi hujan sebesar 6.38 yang terdapat pada saniter wing 1 . Nilai $\mathrm{pH}$ terendah memiliki nilai yang tidak sesuai dengan standar baku mutu yaitu kurang dari 6.5. Berdasarkan metode STORET mutu air dari bangunan GWT Sungai Cihideung sampai dengan Gedung baru Fakultas Ekonomi dan Manajemen menurut sistem US-EPA termasuk kedalam Kelas B yang artinya cemar ringan.

3. Berdasarkan pengaruh waktu dan cuaca didapatkan bahwa kualitas air pada saat pagi cerah cenderung lebih baik dibandingkan dengan pada saat kondisi pagi hujan, sore hujan, dan sore cerah.

\section{SARAN}

Pengukuran kualitas air untuk gedung yang lain perlu dilakukan terutama untuk gedung di IPB yang sudah lama dan hasil pengukurannya dapat dibandingkan dengan pengukuran pada gedung baru.

\section{DAFTAR PUSTAKA}

Arsyad S. 2000. Konservasi Tanah dan Air. Bogor (ID) : IPB Pr.

Atmojo T, Yuni BT, Radjasa OK, Sabdono A. 2003. Kandungan Koprostanol dan Bakteri Coliform pada Lingkungan Perairan Sungai, Muara dan Pantai di Banjir Kanal Timur, Semarang pada Monsun Timur. Jurnal Ilmu Kelautan. 9(1): 54-60.

Boyd. 1982. Water Quality

Management for Pond Fish

Culture. New York (US) :

Elsevier Science Pub. Co. Inc.

[BSN] Badan Standardisasi Nasional. 2005. Cara Uji Fluorida Secara Spektofotometri dengan SPADNS. SNI 06-6989-2005. Jakarta (ID): BSN

[BSN] Badan Standardisasi Nasional. 2009. Cara Uji Klorida dengan Metode Argenometri. SNI 6989.192009. Jakarta (ID): BSN

[BSN] Badan Standardisasi Nasional. 2009. Cara Uji Sulfat Secara Turbidimetri. SNI 6989.20-2009. Jakarta (ID): BSN

[BSN] Badan Standardisasi Nasional. 2012. Kualitas Air-Pengambilan Contoh-Bagian 5; Pengambilan contoh air minum dari instalasi pengolahan air dan sistem jaringan distribusi perpipaan. SNI 78282012. Jakarta (ID): BSN.

Cerny K, Kordylas M, Pospisil F, Svabensky O, Zajic B. 1971. Nutritive value of the winged bean (Paophocarpus palustris Desv). British J. Nutrition 26: 293-299.

Fardiaz S. 1992. Polusi Air dan Udara. Yogayakarta (ID) : Kansius. [KemenKesRI] Kementerian Kesehatan Republik Indonesia. 2017. Standar Baku

Mutu Kesehatan Lingkungan dan Persyaratan Kesehatan Air Untuk 
Keperluan Higiene Sanitasi, Kolam Renang, Solus Per Aqua, dan Pemandian Umum. Keputusan Menteri Kesehatan Republik Indonesia Nomor 32 tahun 2017. Jakarta (ID) : Kementerian Kesehatan Republik Indonesia.

[KemenLH] Kementerian Negara Lingkungan Hidup. 2003. Pedoman Penentuan Status Mutu Air. Keputusan Menteri Negara Lingkungan Hidup nomor 115 tahun 2003. Jakarta (ID) : Kementerian Lingkungan Hidup.

Kurniawan AP. 2014. Faktor-faktor yang Mempengaruhi Kadar Besi (Fe) padaAir Sumur Gali (Studi Penelitian di Desa Beringin Jaya Kecamatan Bolano,Kabupaten Parigi Montong, Provinsi Sulawesi Tengah) [skripsi]. Gorontalo (ID) : Universitas Negeri Gorontalo.

Lazuardi W. 2016. Pemantauan kondisi kualitas air dan udara dalam ruangan di Gedung Andi Hakim Nasoetion Institut Pertanian Bogor [skripsi]. Bogor (ID) : Institut Pertanian Bogor.

Pescod M B. 1973. Investigation of Rational Effluent and Stream Standar for Tropichal Countries. Bangkok (TH): AIT.

Saraswati SP, Sunyoto, Kironot BA, Hadisusanto S. 2014. Kajian Bentuk dan Sensitivitas Rumus Indeks PI, STORET, CCME untuk Penentuan Status Mutu Periaran Sungai Tropis di Indonesia. Jurnal Manusia dan Lingkungan. 21(2): 129-142.

Sariwati E. 2010. Analisis beban pencemaran Sungai Cihideung sebagai bahan baku pengolahan air di Kampus IPB Dramaga [skripsi]. Bogor (ID) : Institut Pertanian Bogor.

Sofia Y, Tontowi, Rahayu S. 2010. Penelitian pengolahan air sungai yang tercemar oleh bahan organik.
Jurnal Sumber Daya Air. 6(2):145160.

Sutrisno T. 2006. Teknologi Penyediaan Air Besih. Jakarta (ID) : Rineka Cipta. Tebbut THY. 1992. Principles of Water Quality Control 4th ed. Oxford (GB): Pergamon Press.

Waspodo RSB, Rahayu D, Komariah S. 2013. Efektivitas riverbank filtration terhadap parameter fisik (TDS) di Sungai Chideung. Jurnal Keteknikan Pertanian. 1(1) : 117-121.

Yudhantoro WA. 2017. Analisis kualitas air pada jalur distribusi air bersih di Gedung Andi Hakim Nasuiton Kampus Institut Pertanian Bogor [skripsi]. Bogor (ID) : Institut Pertanian Bogor. 
